\title{
五年制高职院校自主招生班学生特点分析及班主任工作的 几点思考
}

\section{Analysis on the Characteristics of Students in the Independent Enrollment Class of Five-Year Higher Vocational Colleges and Some Thoughts on the Work of Head Teachers}

\author{
龚魏魏 \\ Weiwei Gong \\ 常州旅游商贸高等职业技术学校 中国·江苏 常州 213000 \\ Changzhou Technical Institute of Tourism \& Commerce, Changzhou, Jiangsu, 213000, China
}

摘 要：通过分析五年制高职校自主招生班学生特点，发现其存在问题，通过深度思考，针对目前存在的问题，提出了班 主任工作的几点思路

\begin{abstract}
Through the analysis of the characteristics of the students in the self-enrollment class of the five-year higher vocational schools, this paper finds out the existing problems, and puts forward some ideas about the work of the head teacher in view of the existing problems through deep thinking.
\end{abstract}

关键字：五年制高职；自主招生班；学生特点；对策

Keywords : five-year higher vocational schools; self-enrollment class; students' characteristics; countermeasures

DOI: $10.36012 /$ sde.v2i11.2415

\section{1 引言}

江苏省五年制高职校自主招生工作改革已实施多年 , 最 初的愿望是招到对应试教育不大适应而具有一些特殊才能 的学生，但是由于生源逐年减少和高中录取比例的提升等原 因，目前自主招生的学生质量水平有下降的趋势，面对自主 招生学生较难管理的情况，需要教育工作者通过思考获得相 应的解决办法。

\section{2 学生特点}

笔者从事江苏省五年制高职自主招生班班主任兼任课 教师已有五年, 在管理与教学过程中对于自主招生班学生有 了一定程度的了解, 与普通大专班学生相比, 他们呈现出了 以下特点。

\section{1 学习意志力较弱, 专注力欠缺}

由于自主招生制度，他们自上学开始从未经历过重大
考试的考验，缺乏这种考验对身心的打磨，导致自身的专注 度不够，很难全身心投入去迎接有难度的挑战, 并且具有较 大的畏难情绪 ${ }^{[1]}$ 。升学大考的缺席, 导致他们难以承受学习 上的各种压力, 很容易觉得事情很难, 自己肯定不行, 导致 总体学生趋于平庸。

2.2 自我学习能力有待提高, 对老师的依赖性较强 作为任课老师和班主任, 常常发现一到自习课, 班上 很少有学生能按照自己的学习计划, 有条不紊地进行自我学 习。大部分学生认为完成老师的作业即可, 如果遇到作业量 少的时候，便是无所适从，胡乱消遣。笔者分析出现这种的 情况的原因是长期缺乏压力，内心努力向上的动力机制被闲 置过久, 导致生活学习中缺乏向一个目标奋不顾身努力的内 驱力。

2.3 自信心不足, 内心十分需要老师的肯定与鼓励 笔者刚开始接触他们的时候, 发现他们有着普通班学

【作者简介】龚魏魏 $(1983 \sim)$, 女, 江苏常州人, 讲师, 从事旅游管理研究。 
生没有的“淡定”与“佛系”，对班级事务漠不关心，对老 师的关注也无所谓。但是通过平日里对他们的持续观察与课 后的谈心沟通，发现他们“冷漠”的外表仅仅是因为他们不 够自信, 怕自己很多事情做不好, 所以索性装出一副不在乎 的模样作为盔甲保护自己。

\section{4 好奇心不够，缺乏探索力，很少质疑}

作为任课教师，在自主招生班上课与普通班上课时的 感受差异十分明显。自主班学生习惯于被动接受, 认为书上 讲的，老师说的就一定是对的，很少会去问为什么，导致课 堂氛围往往比较沉间, 师生互动很难开展, 常常是老师自问 自答。而且无论老师怎么试图调动他们的积极性，效果都很 微小, 进而, 发现他们的精神状态不是很好, 缺乏朝气, 一 到下课，几乎全部的学生都会跌在桌上睡觉。

\section{5 缺乏主见，容易被说服}

在自主招生班授课时，当问他们对一件事、一个问题 看法的时候, 全班几乎无人会大胆的表达自己的见解，严 格来说, 不是他们不敢说, 是压根没有想法。他们习惯用 用渴求并带着期待的目光看着教师，等着教师告诉他们这 件事应该怎么看。当然在班主任管理过程中，这也是一把 双刃剑，他们的这个特点让教师比较容易对他们进行常规 管理，他们很少会去反驳质疑学校的一些规定，比起普通 班学生相对来说比较省心, 比较利于班级管理 ${ }^{\left[{ }^{[2]}\right.}$ 。

\section{3 关于五年制高职自招班班主任工作的几点 思考}

3.1 利用考证机会激发他们的学习能力, 提升锻炼 其专注力

以笔者所带专业为例，本班学生专业是旅游管理，而对 这个专业来讲, 导游人员资格证是唯一一张对他们就业异常 重要的证件, 而且具有一定的难度, 全省每年的通过率不到 $30 \%$, 这也是目前为止他们人生中第一次的考学挑战，笔者 作为班主任和专业任课教师积极的鼓励监督他们，并全程陪 伴他们复习迎考，让他们经历一次为了一个目标奋发努力的 感受, 磨炼他们的心性与意志力, 克服自己身上由于长期缺 乏挑战而产生的惰性。

3.2 定期开展小组读书会, 督促学生提升文化内涵 以增强自信

出生成长在信息时代, 大部分时间与手机为伴, 学生
并没有养成良好的阅读习惯，因此缺乏对知识文化的涉猎， 接受的都是碎片化的信息。长此以往，人会慢慢变浮躁而肤 浅。针对这一情况, 班主任开出书单, 要求学生按照书单每 个月购买或借阅两本好书，每周请两位同学在班会课上分享 自己的读书感受，在培养学生阅读习惯的同时，提升学生的 文化内涵，并且锻炼其表达能力。

\section{3 加强对学生的心理关注}

高职学生，特别是“自招” 学生，很多自认为是无望 高考才选择了高职院校，因此自卑，冷漠，厌学，对自己不 满意, 价值感失落, 总觉得自己是失败和无用的, 对未来迷 惘又失去信心，所以每天浑浑哥哥逃避人生。面对这样的一 群学生, 班主任如果只是简单粗暴地对他们说教，显然是徒 劳的。要用心观察他们的所思所想, 所作所为, 揣测他们内 心最真实的想法与困惑。通过一对一聊天，对他们的消极情 绪进行正面引导，及时疏解。班主任应该为每位同学建立一 份心理档案, 在入校时, 对学生进行心理普测, 测量内容包 括学生的社会适应能力、人格和心理健康等方面, 并篮查出 问题学生形成高危心理档案 ${ }^{[3]}$ 。对于这类有突出心理问题的 学生, 班主任平时更需关注他们的一言一行, 及时与家长保 持沟通, 必要时要请专业的心理工作者进行干预。

3.4 对学生进行未来职业引导, 树立目标, 激发斗志 与普通高等院校不同，高职院校班主任除了管理者的身 份之外，还应该成为学生的职业规划师和人生设计师 ${ }^{[4]}$ 。鼓 励学生根据近几年就业的基本情况对自己的职业发展道路进 行规划和管理，指导他们对既定的学习和生活的目标进行过 渡性地分解，使他们通过渐进性和阶段性的方式逐步实现目 标。高职教育就是就业教育, 高职班主任需要帮助学生实现 学校到职场的无缝对接，在最短时间内适应工作岗位的需要。

\section{参考文献}

[1] 朱吉玉. 高职自主招生学生学习特点和教学改革研究 [J]. 安徽 商贸职业技术学院学报, 2015(9):53-56.

[2] 王卫红 . 根据自主招生班学生特点做好班主任工作 [J]. 中国冶 金教育, 2015(5):78-82.

[3] 谷荣. 自主招生背景下高职院校班主任工作重点 [J]. 九江职业 技术学院学报，2015(4):63-65.

[4] 肖熙妍. 从高职院校学生特点谈班级管理 [J]. 九江职业技术学 院学报, 2008(4):66-67. 